\title{
Pengaruh Faktor Fundamental Terhadap Harga Saham Pada Perusahaan Sektor Pertambangan (Studi Kasus Yang Terdaftar Di Jakarta Islamic Index Tahun 2014-2018)
}

\author{
Intan Tiara Larassati ${ }^{1}$, Hasna Haya Dzikrina ${ }^{2}$, \\ Indun Maulina ${ }^{3}$, Lusi Noviyanti ${ }^{4}$ \\ 1,2,3,4Program Studi Akuntansi, Fakultas Ekonomi dan Bisnis \\ Universitas Singaperbangsa Karawang, Jawa Barat
}

\begin{abstract}
Abstrak. Penelitian ini bertujuan untuk menguji pengaruh Net Profit Margin (NPM), Debt to Equity Ratio (DER), Current Ratio (CR) Terhadap Harga Saham Perusahaan Sektor Pertambangan yang Terdaftar di Jakarta Islamic Index (JII). Data yang digunakan dalam penelitian ini adalah data sekunder yang bersumber dari data laporan keuangan perusahaan di Bursa Efek Indonesia. Populasi yang digunakan dalam penelitian ini adalah seluruh perusahaan JII yang terdaftar di Bursa Efek Indonesia. Penelitian ini menggunakan teknik purposive sampling dengan kriteria yang telah ditentukan. Jumlah sampel yang digunakan dalam penelitian ini sebanyak 6 (enam) perusahaan. Metode analisis yang digunakan adalah analisis regresi linear berganda. Hasil penelitian menunjukkan bahwa secara parsial Net Profit Margin (NPM), Debt to Equity Ratio (DER), Current Ratio (CR) tidak berpengaruh signifikan terhadap harga saham pada perusahaan pertambangan yang terdaftar di Jakarta Islamic Index.
\end{abstract}

Kata kunci: Net Profit Margin (NPM), Debt to Equity Ratio (DER), Current Ratio (CR), dan Harga Saham.

\section{Pendahuluan}

Investasi salah satu cara untuk mendapatkan penghasilan di masa yang akan datang. Banyak nya investasi dipasar modal akan mengakibatkan meningkatnya jumlah investor yang beralih dari industri perbankan ke industri pasar modal. Investor dalam menanamkan dananya membutuhkan berbagai informasi yang digunakan untuk memprediksi hasil investasi nya dalam pasar modal. Dalam melakukan investasi di pasar modal, investor berharap akan mendapatkan keuntungan besar. Hal ini membuat banyak investor melakukan hal-hal yang 


\section{Buana Akuntansi}

seharusnya dilarang seperti praktik spekulasi, masyir dan gharar yang berpotensi mengacaukan ritme pasar yang seharusnya berjalang dengan efisien.

Perdagangan saham memiliki jenis indeks saham yang bisa dipilih untuk kita berinvestasi. Indeks saham merupakan harga atau nilai saham emiten yang dikelompokkan dalam klasifikasi tertentu. Indeks saham dibuat agar investor memiliki acuan ketika ingin berinvestasi di pasar modal. Saat ini ada 24 jenis indeks saham yang ada di Bursa Efek Indonesia. Salah satu indeks saham yang memenuhi kriteria syariah adalah Jakarta Islamic Index (JII). Pembentukan Jakarta Islamic Index tidak lepas dari kerjasama antara pasar modal Indonesia (BEI) dengan PT. Danareksa Investment Management (PT. DIM) yang telah berkembang sejak tanggal 3 Juli 2000 (EIMI 2017).

Para investor muslim merasa khawarir akan hukum halal berinvestasi yang mengandung banyak spekulasi akhirnya terjawab dengan dikeluarkannya arahan Dewan Syariah Nasional Majelis Ulama Indonesia (DSN-MUI) pada tanggal 18 April 2001 yaitu Fatwa Nomor 20/DSNMUI/IV/2001 tentang pedoman pelaksanaan investasi untuk reksa dana syariah. Bapepam-LK pada tanggal 23 November 2006 menerbitkan Peraturan Bapepam-LK Nomor IX.A.13 tentang penerbitan efek syariah dan dilakukan penyempurnaan pada tanggal 30 Juni 2009. Perkembangan pasar modal syariah mencapai sejarah baru pada tanggal 7 Mei 2008 disahkannya UU Nomor 19 Tahun 2008 tentang Surat Berharga Syariah Negara (SBSN).

Faktor fundamental merupakan faktor yang berhubungan dengan kondisi keuangan perusahaan dengan cara menganalisis data finansial dari laporan keuangan perusahaan, seperti tingkat profitabilitas, tingkat aktivitas, tingkat leverage, dan lainnya (Kartika 2009). Rasio keuangan yang sering digunakan oleh investor sebagai rujukan untuk melihat kondisi kinerja perusahaan, yaitu rasio profitabilitas, rasio solvabilitas dan rasio likuiditas serta kebijakan dividen yang menjadi tidak relevan ketika menentukan harga saham, dimana tidak mempengaruhi keputusan rumusan penetapan laba, hal ini dapat menjadikan peluang investasi yang sama bagi investor dan manajemen kedepannya (Sartono 2014, 281, Husain, et al. 2020).

Rasio Profitabilitas adalah rasio yang digunakan untuk menilai kemampuan perusahaan dalam mencari keuntungan. rasio profitabilitas ditunjukkan oleh laba yang dihasilkan dari penjualan dan pendapatan investasi perusahaan (Kasmir 2016, 115). Net Profit Margin (NPM) adalah ukuran keuntungan dengan membandingkan antara laba setelah pajak dengan penjualan yang menunjukkan kinerja keuangan perusahaan dalam menghasilkan laba bersih atas total penjualan bersih yang dihasilkan oleh perusahaan. Jadi, kinerja keuangan perusahaan dalam menghasilkan laba bersih atas penjualan bersihnya semakin meningkat akan berdampak pada meningkatnya pendapatan yang akan diterima oleh para pemegang saham (Sapariyah, et al. 2017). Jika permintaan atas saham perusahaan semakin banyak maka harga saham di pasar modal akan meningkat. Rasio ini juga dapat dianalisis untuk melihat sejauh mana suatu perusahaan memiliki kinerja keuangan baik dan benar dengan menggunakan aturan-aturan tersebut (Fahmi 2017, 239, Yanti, Isyanto dan Mohd Saudi 2020).

Rasio Solvabilitas adalah rasio yang digunakan untuk mengukur kemampuan perusahaan untuk membayar seluruh kewajiban perusahaan yang meliputi utang jangka panjang dan utang jangka pendek dalam perusahaan masih berjalan maupun dalam keadaan dibubarkan (Purba 2015). Debt to Equity Ratio (DER) adalah salah satu rasio solvabilitas yang menunjukkan besarnya biaya total aktiva yang pembiayaannya berasal dari total utang. Semakin besar angka DER perusahaan maka semakin tinggi risiko yang dimiliki perusahaan dalam menutupi utang 


\section{Buana Akuntansi}

perusahaan. Para investor akan berfikir panjang untuk menanamkan modal pada perusahaan dengan angka DER yang tinggi, sehingga permintaan saham akan menurun dan harga saham akan ikut turun.

Rasio Likuiditas adalah rasio yang digunakan untuk mengukur kemampuan perusahaan dalam memenuhi kewajiban jangka pendek. Current Ratio (CR) adalah rasio dengan seberapa banyak aktiva lancar yang tersedia untuk menutupi kewajiban jangka pendek yang segera jatuh tempo, dengan cara membandingkan antara total aktiva lancar dengan total utang lancar (Purba 2015). Tingginya Current Ratio menunjukkan keyakinan investor terhadap kemampuan perusahaan untuk membayarkan dividen yang dijanjikan kepada investor. Pembayaran dividen merupakan arus kas keluar, sehingga semakin kuat posisi aktiva yang dimiliki perusahaan makan semakin besar pula kemampuan perusahaan dalam membayarkan dividen kepada para pemegang saham dan perubahan harga saham akan mendatangkan keuntungan atau kerugian atas selisih penjualan saham (Nurfadillah, Kamaratih dan Hamka 2019). Semakin tinggi tingkat pengembalian yang akan di dapatkan investor, semakin banyak pula permintaan akan saham perusahaan. Jika semakin banyak permintaan saham makan akan meningkatkan harga saham.

Faktor fundamental terhadap harga saham dapat ditinjau dari laporan keuangan perusahaan yang telah diaudit khususnya pada perusahaan yang listing di Bursa Efek Indonesia (BEI). Indonesia yang saat ini sedang menghadapi persoalan dalam konteks MEA harus menekankan pihak independen dalam menjaga kualitas auditnya (Husain dan Syniuta 2020), hasil ini tentunya akan sangat mendukung dalam menentukan pergerakan harga saham. Hasil penelitian Nunuk Idamanti (2016) menyatakan bahwa likuiditas, profitabilitas dan penjualan mempunyai pengaruh signifikan terhadap harga saham. Dian Ramadhan Kelana,dkk. (2017) menyatakan bahwa ROA, CR, EPS dan DER menjadi analisis teknikal dan fundamental dalam menggambarkan bagian indikator finansial yang menggambarkan kinerja yang berkaitan dengan harga saham. CR, DER, ROA dan NPM yang mempengaruhi harga saham pada penelitian Vera Ch.O Manoppo, dkk. (2017), hanya dibuktikan pengaruhnya oleh ROA dan NPM sementara CR dan DER tidak berpengaruh terhadap Harga Saham. Analisis pengaruh Current Ratio, Return on Assets, Debt to Equity Ratio dan tingkat pertumbuhan terhadap kebijakan dividen yang hanya dibuktikan oleh variabel tingkat pertumbuhan (Nurfadillah, Kamaratih dan Hamka 2019).

Berdasarkan beberapa hasil penelitian terdahulu, penelitian ini bertujuan untuk menganalisis pengaruh Net Profit Margin, Debt to Equity Ratio, Current Ratio dan Net Profit terhadap Harga Saham baik secara simultan dan parsial. Penelitian ini menggunakan objek penelitian pada perusahaan sub-sektor Pertambangan yang terdaftar di Jakarta Islamic Index (JII) dengan akhir tahun pembukuan pada tanggal 31 Desember 2014, 2015, 2016 dan 2018.

\section{Tinjauan Pustaka}

Pasar modal adalah tempat yang mempertemukannya suatu permintaan dan penawaran atas instrument keuangan yang berjangka Panjang, yang biasanya lebih dari satu tahun (Samsul 2015, 57). Rasio keuangan menggambarkan suatu hubungan atau perbandingan nilau suatu akun dengan nilai akun yang lainnya dalam laporan keuangan (Sujarweni 2017, 59).

Current Ratio (CR) atau utang lancer merupakan rasio pengukur kinerja keuangan neraca

likuiditas perusahaan. Rasio ini menampilkan kemampuan perusahaan untuk menunaikan 


\section{Buana Akuntansi}

kewajiban utang jangka pendeknya pada satu tahun ke depan. Calon kreditur mempergunakan rasio ini untuk mengetahui apakah kreditur akan memberikan pinjaman atau tidak kepada perusahaan tersebut. Debt to equity ratio (DER) atau rasio utang terhadap ekuitas atau rasio utang modal yaitu bagian dari rasio keuangan yang menunjukan bagian antara ekuitas dan utang yang dipakai untuk membiayai aset perusahaan. Rasio ini digunakan untuk menilai posisi keuangan suatu perusahaan. Perusahaan yang memiliki nilai DER atas rasio utang terhadap ekuitas yang besar tidak dapat mempengaruhi untuk mendapatkan tambahan modal dari investor. Net Profit Margin (NPM) bagian dari profitability ratio yang dipakai untuk mengukur persentase besar kecilnya laba bersih dalam kegiatan penjualan. Bagi calon investor, rasio NPM ini untuk mengukur efisiensi manajemen dalam mengelola perusahaan dan memperkirakan profitabilitas di masa yang akan datang.

Hipotesis penelitian dirumuskan:

$\mathrm{H}_{1}=$ Net Profit Margin (NPM) berpengaruh signifikan terhadap Harga Saham.

$\mathrm{H}_{2}=$ Debt to Equity Ratio (DER) berpengaruh signifikan terhadap Harga Saham.

$\mathrm{H}_{3}=$ Current Ratio (CR) berpengaruh signifikan terhadap Harga Saham.

$\mathrm{H}_{4}=$ Net Profit Margin (NPM), Debt to Equity Ratio (DER), Current Ratio (CR), berpengaruh signifikan terhadap Harga Saham

\section{Metodologi Penelitian}

Penelitian ini adalah jenis deskriptif yang menjelaskan dari data-data kuantitatif yang digunakan. Penelitian ini dilakukan pada perusahaan yang listing di kategori Jakarta Islamic Index (JII) pada tahun 2014-2018. Populasi pada penelitian ini adalah perusahaan yang listing di JII (Jakarta Inslamic Index) sebanyak 30 perusahaan. Sedangkan yang diambil sebagai sampel sebanyak 6 perusahaan emiten sub sektor pertambangan yang terdaftar di Jakarta Islamic Index.

Data yang digunakan adalah data sekunder yaitu berupa laporan keuangan tahunan Perusahaan Subsektor Pertambangan yang terdaftar di Jakarta Islamic Index dengan akhir tahun pembukuan pada tanggal 31 Desember 2014, 2015, 2016 dan 2018. Sumber data diperoleh dari https://idx.co.id/

Variabel dalam penelitian ini adalah sebagai berikut:

1. Variabel bebas atau variable independent $(\mathrm{x})$ yang terdiri dari rasio - rasio keuangan yang digunakan yaitu CR, DER, dan NPM

2. Variabel terikat atau variable dependent (y) yaitu harga saham yang diambil dari ratarata harga saham penutupan dalam 1 tahun dari tahun 2014-2018.

Teknik analisa data menggunakan kerangka konsep analisis regresi linear berganda, untuk mencari pengaruh variabel independen terhadap variabel dependennya, baik secara simultan maupun parsial, dengan menggunakan program SPSS (Statistical Package for the Social Science) versi 21. Berikut ini persamaan regresi linear berganda (Ghozali 2017):

$Y=a+b_{1} X_{1}+b_{2} X_{2}++b_{3} X_{3+} e$

Keterangan :

$\mathrm{Y}=$ Harga Saham

$\mathrm{a}=$ Konstanta

$\mathrm{b}_{1}=$ Koefisien regresi variable Current Ratio (CR) 


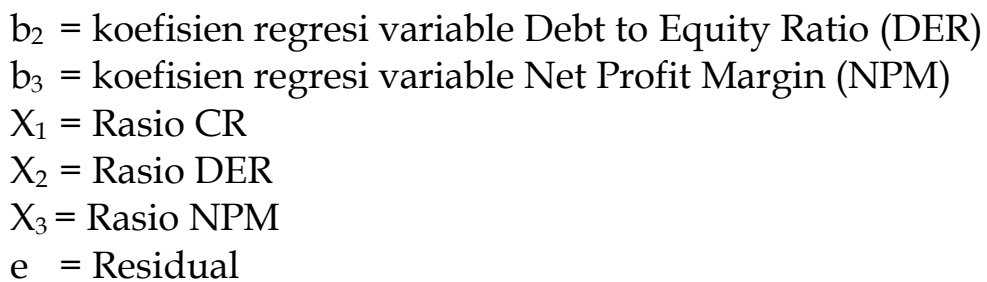

Untuk mengetahui pengaruh variabel ROA, ROE, DER dan EPS terhadap harga saham, dilakukan uji baik secara simultan maupun secara parsial dengan tingkat kepercayaan 95\% $(\alpha=$ $5 \%$ ).

Uji $t$ adalah pengujian secara statistik untuk mengetahui apakah variabel-variabel independen mempunyai pengaruh terhadap variabel dependen, jika nilai signifikasi < 0,05 maka hipotesis diterima yang berarti variable Current Ratio (CR), Debt to Eqyuity Ratio (DER) dan Net Profit Margin (NPM) berpengaruh terhadap Harga Saham, atau sebaliknya jika nilai > 0,05 maka hipotesis ditolak yang berarti variable Current Ratio (CR), Debt to Eqyuity Ratio (DER) dan Net Profit Margin (NPM) tidak berpengaruh terhadap Harga Saham.

Uji $t$ adalah pengujian secara statistik atau uji signifikasi simultan adalah menunjukkan semua variabel independen atau bebas yang dimasukkan dalam model mempunyai pengaruh secara bersama-sama terhadap variabel dependen (terikat) (Ghozali 2017, 98). Kriteria pengambilan keputusan adalah jika nilai signifikasi < 0,05 maka hipotesis diterima yang berarti variable perputaran Current Ratio (CR), Debt to Eqyuity Ratio (DER) dan Net Profit Margin (NPM) sesuai sebagai variable penjelas terhadap variable harga saham. Atau sebaliknya, jika nilai signifikasi > 0,05 maka hipotesis ditolak yang berarti variable perputaran Current Ratio (CR), Debt to Eqyuity Ratio (DER) dan Net Profit Margin (NPM) tidak sesuai sebagai variable penjelas terhadap variable profitabilitas.

\section{Analisis dan Pembahasan}

4.1. Hasil Statistik Deskriptif

Tabel 1. Analisis Statistik Deskriptif

\begin{tabular}{|l|r|r|r|r|r|}
\hline \multicolumn{1}{|c|}{ N } & Minimum & Maximum & Mean & \multicolumn{1}{c|}{$\begin{array}{c}\text { Std. } \\
\text { Deviation }\end{array}$} \\
\hline NPM & 30 & $-13,68$ & 29,27 & 7,5643 & 10,65376 \\
DER & 30 &, 17 & 2,26 &, 7603 &, 52318 \\
CR & 30 & 154,35 & 461,76 & 237,4783 & 83,72014 \\
Harga_Saham & 30 & 108,00 & 20700,00 & 4059,0667 & 5899,17658 \\
Valid N (listwise) & 30 & & & & \\
\hline
\end{tabular}

Sumber: Output SPSS 21

Dari perhitungan statistik deskriptif menunjukkan bahwa nilai minimum untuk bagian NPM adalah sebesar -13,68 yang diperoleh dari Aneka Tambang (Persero) Tbk pada tahun 2015, sedangkan untuk nilai maksimum NPM adalah sebesar 29,27 yang diperoleh dari PT Indika Energy Tbk pada tahun 2017. Mean atau rata-rata NPM adalah sebesar 7,56. Standar deviasi NPM adalah sebesar 10,65376. Dari perhitungan statistik deskriptif dapat diketahui bahwa DER adalah sebesar 0,17 yang diperoleh dari PT Vale Indonesia Tbk pada tahun 2018, 
sedangkan untuk nilai maksimum untuk bagian DER adalah sebesar 2,26 yang diperoleh dari PT Indika Energy Tbk pada tahun 2017. Untuk bagian Mean atau rata-rata DER adalah sebesar 0,76. Standar deviasi DER adalah sebesar 0,52318 Dari perhitungan statistik deskriptif dapat diketahui bahwa CR adalah sebesar 154,35 yang diperoleh dari PT Bukit Asam Tbk pada tahun 2015, sedangkan untuk nilai maksimum CR adalah sebesar 461,76 yang diperoleh dari PT Vale Indonesia Tbk pada tahun 2017. Untuk bagian mean atau rata-rata adalah sebesar 237,48 dan untuk standar deviasinya adalah sebesar 83,72. Dari perhitungan statistik deskriptif dapat diketahui bahwa Harga saham adalah sebesar 108,00 yang diperoleh dari PT Indika Energy Tbk pada tahun 2015, sedangkan untuk nilai maksimum harga saham adalah sebesar 20.700,00 yang diperoleh dari PT Indo Tambangraya Megah Tbk pada tahun 2017. Untuk bagian rata-rata adalah sebesar 4059,07 dan untuk standar deviasinya adalah sebesar 5899,17658.

\subsection{Hasil Uji Asumsi Klasik}

Tabel 2. Hasil Uji Kolmogorov-Smirnov (K/S)

\begin{tabular}{|c|c|c|}
\hline & & $\begin{array}{c}\text { Unstandardized } \\
\text { Residual }\end{array}$ \\
\hline \multicolumn{2}{|l|}{$\mathrm{N}$} & 30 \\
\hline \multirow{3}{*}{ Normal Parameters ${ }^{a, b}$} & Mean & ,0000000 \\
\hline & Std. Deviation & 5221,64221086 \\
\hline & Absolute & , 185 \\
\hline \multirow[t]{2}{*}{ Most Extreme Differences } & Positive & ,185 \\
\hline & Negative &,- 161 \\
\hline Kolmogorov-Smirnov Z & & 1,011 \\
\hline Asymp. Sig. (2-tailed) & & ,258 \\
\hline
\end{tabular}

Sumber: Output SPSS 21

Berdasarkan tabel Kolmogorov-Smirnov di atas menujukkan bahwa nilai Asymp. Sig adalah 0,258 yang berarti data tersebut memiliki nilai Asymp. Sig > 0,05 maka dapat disimpulkan bahwa data yang digunakan atau diolah sudah berdistribusi normal.

Tabel 3. Hasil Uji Multikolinearitas

\begin{tabular}{|c|c|c|c|c|c|c|c|}
\hline & & & Coefficients $^{a}$ & & & & \\
\hline \multirow[t]{2}{*}{ Model } & \multicolumn{2}{|c|}{$\begin{array}{l}\text { Unstandardized } \\
\text { Coefficients }\end{array}$} & \multirow{2}{*}{$\begin{array}{c}\text { Standardized } \\
\text { Coefficients } \\
\text { Beta }\end{array}$} & \multirow[t]{2}{*}{$\mathrm{t}$} & \multirow[t]{2}{*}{ Sig. } & \multicolumn{2}{|c|}{$\begin{array}{l}\text { Collinearity } \\
\text { Statistics }\end{array}$} \\
\hline & B & Std. Error & & & & Tolerance & VIF \\
\hline \multirow{4}{*}{1} & 9625,307 & 4516,997 & & 2,131 & ,043 & & \\
\hline & 149,763 & 96,913 & ,270 & 1,545 & ,134 & ,984 & 1,017 \\
\hline & $-4358,800$ & 2185,901 &,- 387 & $-1,994$ & ,057 & 802 & 1,247 \\
\hline & $-14,254$ & 13,670 &,- 202 & $-1,043$ & ,307 & 801 & 1,249 \\
\hline
\end{tabular}

Sumber: Output SPSS 21 
Berdasarkan tabel Kolmogorov-Smirnov di atas menujukkan bahwa nilai Asymp. Sig adalah 0,258 yang berarti data tersebut memiliki nilai Asymp. Sig > 0,05 maka dapat disimpulkan bahwa data yang digunakan atau diolah sudah berdistribusi normal. Tabel 3 diketahui bahwa nilai VIF untuk masing-masing variabel:

1. Nilai VIF untuk $X_{1}$ (Net Profit Margin) adalah 1,017 yang artinya berada pada nilai antara 1-10, hal ini menunjukkan bahwa variable $X_{1}$ tidak terjadi multikolinearitas.

2. Nilai VIF untuk $X_{2}$ (Debt to Equity Ratio) adalah 1,247 yang artinya berada pada nilai antara 1-10, hal ini menunjukkan bahwa variable $X_{2}$ tidak terjadi multikolinearitas.

3. Nilai VIF untuk $X_{3}$ (Current Ratio) adalah 1,249 yang artinya berada pada nilai antara 110 , hal ini menunjukkan bahwa variable $X_{3}$ tidak terjadi multikolinearitas.

Berdasarkan penjelasan diatas, dapat disimpulkan bahwa tidak terjadi multikolinearias antar variable independen dalam model regresi, karena tidak terjadi kolinearitas yang tinggi antara variable independen dalam persamaan regresi yang diperoleh.

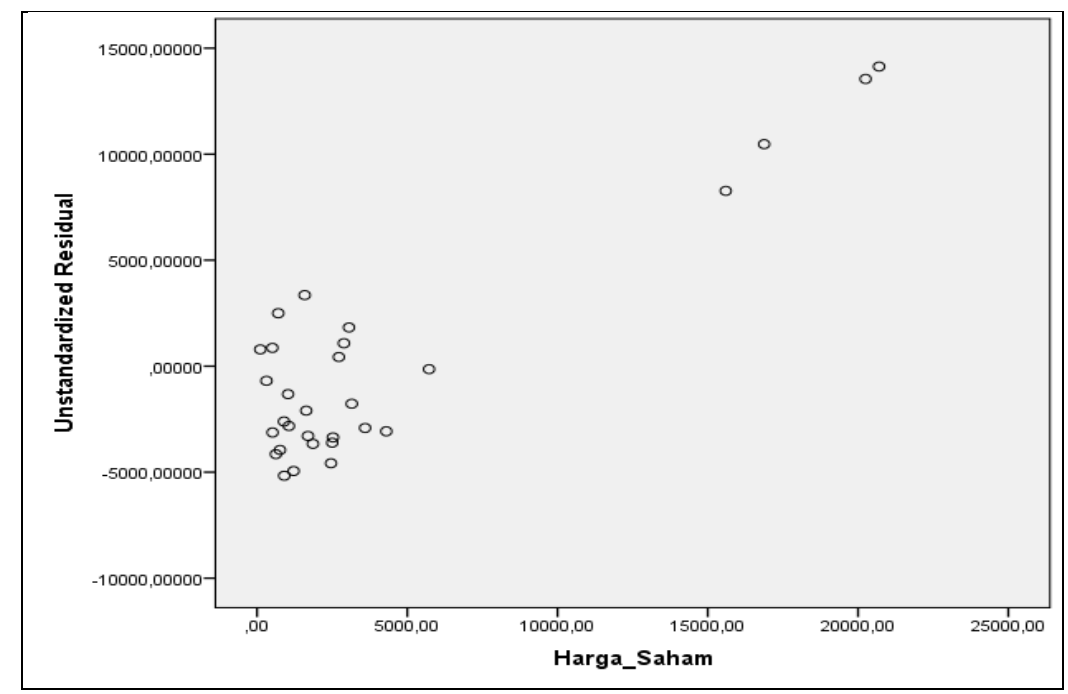

Sumber: Output SPSS 21

\section{Gambar 1: Scatterplot Uji Heteroskedastisitas}

Grafik scatterplot di atas terlihat bahwa titik-titik plot tidak hanya berada di satu titik tempat atau menyebar di atas dan atau di bawah angka 0, penyebaran titik tersebut tidak membentuk sebuah pola maka dapat disimpulkan bahwa data tidak terjadi problem heteroskedastisitas pada model regresi.

Tabel 4. Hasil Uji Autokorelasi

Model Summary ${ }^{b}$

\begin{tabular}{|l|r|r|r|r|r|}
\hline Model & \multicolumn{1}{l|}{$\mathrm{R} r \mathrm{R}$ Square } & $\begin{array}{c}\text { Adjusted R } \\
\text { Square }\end{array}$ & $\begin{array}{l}\text { Std. Error of } \\
\text { the Estimate }\end{array}$ & $\begin{array}{c}\text { Durbin- } \\
\text { Watson }\end{array}$ \\
\hline 1 & ${ }^{4} 465^{\mathrm{a}}$ &, 217 &, 126 & 5514,66881 &, 717 \\
\hline
\end{tabular}




\section{Buana Akuntansi}

Sumber: Output SPSS 21

Berdasarkan nilai tabel pada tingkat siginifkan 5\%, n menunjukkan jumlah sampel sebesar 30 dan jumlah variabel independen $3(\mathrm{k}=3)$, Nilai Durbin-Watson dari hasil analisis adalah 0,717. Dengan demikian akan diperoleh nilai dl: 1,2138 du:1,6498. Maka nilai autokorelasi diantara 1,2138 > 0,717 < 1,6498 itu berarti menunjukkan bahwa tidak terjadi autokorelasi pada variabel dalam penelitian ini.

\subsection{Hasil Uji Analisis Regresi Berganda}

Tabel 5. Hasil Uji Koefisien Regresi

Coefficients $^{\mathrm{a}}$

\begin{tabular}{|c|c|c|c|c|c|c|}
\hline \multirow{2}{*}{\multicolumn{2}{|c|}{ Model }} & \multicolumn{2}{|c|}{$\begin{array}{c}\text { Unstandardized } \\
\text { Coefficients }\end{array}$} & \multirow{2}{*}{$\begin{array}{c}\text { Standardized } \\
\text { Coefficients } \\
\text { Beta }\end{array}$} & \multirow[t]{2}{*}{$\mathrm{t}$} & \multirow[t]{2}{*}{ Sig. } \\
\hline & & B & Std. Error & & & \\
\hline \multirow{4}{*}{1} & (Constant) & 9625,307 & 4516,997 & & 2,131 & ,043 \\
\hline & NPM & 149,763 & 96,913 & 270 & 1,545 & 134 \\
\hline & DER & $-4358,800$ & 2185,901 &,- 387 & $-1,994$ & ,057 \\
\hline & $\mathrm{CR}$ & $-14,254$ & 13,670 &,- 202 & $-1,043$ & ,307 \\
\hline
\end{tabular}

a. Dependent Variable: Harga_Saham

Sumber: Output SPSS 21

Hasil pengolahan data tabel 5 di atas, maka dapat diperoleh hasil regresi linear berganda sebagai berikut:

1. Pengaruh Net Profit Margin Terhadap Harga Saham

a. Persamaan Regresi Berganda

Y $=9.625,307+149,763$ NPM

Artinya bahwa setiap kenaikan net profit margin sebesar $1 \%$ maka harga saham perusahaan akan mengalami peningkatan sebesar 149,763 dengan asumsi variabel lain tetap pada Perusahaan Sektor Pertambangan yang terdaftar di Jakarta Islamic Index.

b. Koefisien Determinasi

$\mathrm{CD}=\mathrm{R}^{2} \times 100 \%$

Tabel 6. Hasil Uji Koefisien Determinasi $\left(\mathbf{R}^{2}\right)$ - Harga Saham

Model Summaryb

\begin{tabular}{|l|r|r|r|r|r|} 
Model & R & R Square & $\begin{array}{c}\text { Adjusted R } \\
\text { Square }\end{array}$ & $\begin{array}{c}\text { Std. Error of } \\
\text { the Estimate }\end{array}$ & $\begin{array}{r}\text { Durbin- } \\
\text { Watson }\end{array}$ \\
\hline 1 &, $054^{a}$ &, 003 &,- 033 & 5994,87822 &, 784 \\
\hline
\end{tabular}

a. Predictors: (Constant), CR

b. Dependent Variable: Harga_Saham

Sumber: Output SPSS 21 


\section{Buana Akuntansi}

Vol. 5 No. 2

ISSN 2528-1119

E-ISSN 2580-5452

Hasil analisis pada tabel 6 dengan menggunakan program SPSS diketahui bahwa besarnya nilai $R$ Square $=0,033$ atau 3,3\% yang berarti kemampuan variabel net profit margin memperngaruhi perubahan harga saham sebesar 3,3\%, sedangkan $96,7 \%$ dipengaruhi oleh variabel lain di luar persamaan regresi berganda atau yang tidak diteliti dalam penelitian ini.

2. Pengaruh Debt to Equity Ratio Terhadap Harga Saham

a. Persamaan Regresi Berganda $\mathrm{Y}=9.625,307+(-4.358,800)$ DER

Artinya bahwa setiap kenaikan debt to equity ratio sebesar $1 \%$ maka harga saham perusahaan akan mengalami penurunan sebesar $-4.358,800$ dengan asumsi variabel lain tetap pada Perusahaan Sektor Pertambangan yang terdaftar di Jakarta Islamic Index.

b. Koefisien Determinasi

$\mathrm{CD}=\mathrm{R}^{2} \times 100 \%$

Tabel 7. Hasil Uji Koefisien Determinasi $\left(\mathbf{R}^{2}\right)$ - Debt to Equity Ratio Model Summaryb

\begin{tabular}{|l|r|r|r|r|r|} 
Model & $\mathrm{R}$ & R Square & $\begin{array}{c}\text { Adjusted R } \\
\text { Square }\end{array}$ & $\begin{array}{c}\text { Std. Error of } \\
\text { the Estimate }\end{array}$ & $\begin{array}{c}\text { Durbin- } \\
\text { Watson }\end{array}$ \\
\hline 1 &, $315^{\mathrm{a}}$ &, 100 &, 067 & 5697,06507 &, 713 \\
\hline
\end{tabular}

a. Predictors: (Constant), DER

b. Dependent Variable: Harga_Saham

Sumber: Output SPSS 21

Hasil analisis pada tabel 7 dengan menggunakan program SPSS diketahui bahwa besarnya nilai $R$ Square $=0,100$ atau $10 \%$ yang berarti kemampuan variabel debt to equity ratio memperngaruhi perubahan harga saham sebesar 10\%, sedangkan 90\% dipengaruhi oleh variabel lain di luar persamaan regresi berganda atau yang tidak diteliti dalam penelitian ini.

3. Pengaruh Current Ratio Terhadap Harga Saham

a. Persamaan Regresi Berganda $Y=9.625,307+(-14,254) C R$

Artinya bahwa setiap kenaikan debt to equity ratio sebesar 1\% maka harga saham perusahaan akan mengalami penurunan sebesar -14,254 dengan asumsi variabel lain tetap pada Perusahaan Sektor Pertambangan yang terdaftar di Jakarta Islamic Index.

b. Koefisien Determinasi

$\mathrm{CD}=\mathrm{R}^{2} \times 100 \%$ 


\section{Buana Akuntansi}

Tabel 8. Hasil Uji Koefisien Determinasi ( $\left.\mathbf{R}^{2}\right)$ - Current Ratio Model Summary ${ }^{b}$

\begin{tabular}{|l|r|r|r|r|r|} 
Model & $\mathrm{R}$ & R Square & $\begin{array}{c}\text { Adjusted R } \\
\text { Square }\end{array}$ & $\begin{array}{r}\text { Std. Error of } \\
\text { the Estimate }\end{array}$ & $\begin{array}{r}\text { Durbin- } \\
\text { Watson }\end{array}$ \\
\hline 1 &, $054^{\mathrm{a}}$ &, 003 &,- 033 & 5994,87822 &, 784 \\
\hline
\end{tabular}

a. Predictors: (Constant), CR

b. Dependent Variable: Harga_Saham

Sumber: Output SPSS 21

Hasil analisis pada tabel 8 dengan menggunakan program SPSS diketahui bahwa besarnya nilai $R$ Square $=0,003$ atau $0,3 \%$ yang berarti kemampuan variabel debt to equity ratio memperngaruhi perubahan harga saham sebesar 0,3\%, sedangkan 99,7\% dipengaruhi oleh variabel lain di luar persamaan regresi berganda atau yang tidak diteliti dalam penelitian ini.

4. Pengaruh Net Profit Margin, Debt to Equity Ratio dan Current Ratio Terhadap Harga Saham

a. Persamaan Regresi Berganda $Y=9.625,307+149,763 X_{1}+(-4.358,800) X_{2}+(-14,254) X_{3}+e$

Dari persamaan regresi linear berganda dapat diartikan sebagai berikut:

a) Konstanta (a) positif sebesar 9.625,307, artinya apabila net profit margin, debt to equity ratio, dan curren ratio dalam keadaan tetap, maka harga saham pada Perusahaan Sektor Pertambangan yang Terdaftar di Jakarta Islamic Index akan meningkat.

b) Koefisien regresi net profit margin sebesar 149,763, dengan nilai positif. Hasil ini memberikan pengertian yaitu setiap ada peningkatan $1 \%$ pada net profit margin maka akan mampu meningkatkan 149,763 harga saham pada Perusahaan Sektor Pertambangan yang Terdaftar di Jakarta Islamic Index.

c) Koefisien regresi debt to equity ratio sebesar $-4.358,800$ dengan nilai negatif. Hasil ini memberikan pengertian yaitu setiap ada peningkatan $1 \%$ pada debt to equity ratio akan mampu menurunkan $-4.358,800$ harga saham pada Perusahaan Sektor Pertambangan yang Terdaftar di Jakarta Islamic Index.

d) Koefisien regresi current ratio sebesar -14,254 dengan nilai negatif. Hasil ini memberikan pengertian yaitu setiap ada peningkatan $1 \%$ pada current ratio akan mampu menurunkan -14.254 harga saham pada Perusahaan Sektor Pertambangan yang Terdaftar di Jakarta Islamic Index.

b. Koefisien Determinasi 


\section{Buana Akuntansi}

Tabel 9. Hasil Uji Koefisien Determinasi ( $\left.\mathbf{R}^{2}\right)$

Model Summaryb

\begin{tabular}{|l|r|r|r|r|r|}
\hline Model & $\mathrm{R}$ & R Square & $\begin{array}{c}\text { Adjusted R } \\
\text { Square }\end{array}$ & $\begin{array}{r}\text { Std. Error of } \\
\text { the Estimate }\end{array}$ & $\begin{array}{r}\text { Durbin- } \\
\text { Watson }\end{array}$ \\
\hline 1 &, $465^{\mathrm{a}}$ &, 217 &, 126 & 5514,66881 &, 717 \\
\hline
\end{tabular}

a. Predictors: (Constant), CR, NPM, DER

b. Dependent Variable: Harga_Saham

Sumber: Output SPSS 21

Hasil analisis pada tabel 9 dengan menggunakan program SPSS diketahui besarnya nilai $\mathrm{R}$ Square $=0,217$ atau 21,7\%. Hal tersebut menunjukkan kemampuan variabel-variabel bebas secara bersama-sama yaitu net profit margin, debt to equity ratio, dan current ratio mempengaruhi harga saham sebesar $21,7 \%$ sementara sisanya $78,3 \%$ dipengaruhi oleh variabel lain di luar persamaan regresi berganda atau yang tidak diteliti dalam penelitian ini. Hal ini mengindikasikan ada faktor lain yang mempengaruhi variabel terikat di dalam penelitian ini.

\subsection{Hasil Uji Hipotesis}

\section{Tabel 10. Hasil Uji-t}

Coefficients ${ }^{a}$

\begin{tabular}{|c|c|c|c|c|c|c|}
\hline \multirow{2}{*}{\multicolumn{2}{|c|}{ Model }} & \multicolumn{2}{|c|}{$\begin{array}{c}\text { Unstandardized } \\
\text { Coefficients }\end{array}$} & \multirow{2}{*}{$\begin{array}{c}\text { Standardized } \\
\text { Coefficients } \\
\text { Beta }\end{array}$} & \multirow[t]{2}{*}{$\mathrm{t}$} & \multirow[t]{2}{*}{ Sig. } \\
\hline & & B & Std. Error & & & \\
\hline \multirow{4}{*}{1} & (Constant) & 9625,307 & 4516,997 & & 2,131 & ,043 \\
\hline & NPM & 149,763 & 96,913 & 270 & 1,545 & 134 \\
\hline & DER & $-4358,800$ & 2185,901 &,- 387 & $-1,994$ & ,057 \\
\hline & $\mathrm{CR}$ & $-14,254$ & 13,670 &,- 202 & $-1,043$ & ,307 \\
\hline
\end{tabular}

a. Dependent Variable: Harga_Saham

Sumber: Output SPSS 21

Uji t digunakan untuk melihat pengaruh dari masing-masing variabel independen secara individu dengan melihat tingkat signifikansi. Diketahui $\mathrm{n}=30, \mathrm{k}=4, \mathrm{Df}=26, \mathrm{a}=0,05$, sehingga menghasilkan $t_{\text {tabel }}=2,056$.

\section{Tabel 11. Hasil Uji-F}

ANOVA $^{a}$

\begin{tabular}{|rl|r|r|r|r|r|}
\hline \multicolumn{1}{|c}{ Model } & Sum of Squares & df & Mean Square & F & Sig. \\
\hline \multirow{2}{*}{1} & Regression & 218507369,898 & 3 & 72835789,966 & 2,395 &, $091^{\mathrm{b}}$ \\
& Residual & 790700873,968 & 26 & 30411572,076 & & \\
& Total & 1009208243,867 & 29 & & & \\
\hline
\end{tabular}

a. Dependent Variable: Harga_Saham 


\title{
Buana Akuntansi
}

\author{
b. Predictors: (Constant), CR, NPM, DER \\ Sumber: Output SPSS 21
}

Uji t digunakan untuk melihat pengaruh dari masing-masing variabel independen secara individu dengan melihat tingkat signifikansi. Diketahui $\mathrm{n}=30, \mathrm{k}=4, \mathrm{Df}=26, \mathrm{a}=0,05$, sehingga menghasilkan tabel $=2,056$.

\subsection{Pembahasan Hasil}

\subsubsection{Pengaruh Net Profit Margin (NPM) Terhadap Harga Saham}

Berdasarkan hasil uji t pada tabel 10 diketahui bahwa net profit margin tidak berpengaruh signifikan terhadap harga saham. Hal tersebut dibuktikan dengan hasil uji t dimana nilai $t_{\text {hitung }}$ sebesar 1,545 dan $t_{\text {tabel }}$ sebesar 2,056, sehingga $t_{\text {hitung }}(1,545)<t_{\text {tabel }}(2,056)$ dan dengan nilai signifikan yang lebih besar dari 0,05 yaitu sebesar 0,134 $(0,134>0,05)$. Dengan demikian, dapat diketahui bahwa $\mathrm{H}_{0}$ diterima dan $\mathrm{H}_{1}$ ditolak, yang berarti tidak ada pengaruh yang signifikan antara net profit margin terhadap harga saham. Temuan penelitian ini bertolak belakang dengan hasil penelitian terdahulu yang membuktikan pengaruh NPM terhadap harga saham (Manoppo, Tewal dan Hasan Jan 2017), kemudian NPM tidak memberikan pengaruh terhadap harga saham syariah (Megawati 2018). Hal tersebut mengindikasikan bahwa para investor tidak mempertimbangkan efektivitas perusahaan dalam mengoptimalkan modal yang dimiliki untuk menghasilkan laba bagi perusahaan.

\subsubsection{Pengaruh Debt to Equity Ratio (DER) Terhadap Harga Saham}

Berdasarkan hasil uji $\mathrm{t}$ pada tabel 10 diketahui bahwa debt to equity ratio tidak berpengaruh signifikan terhadap harga saham. Hal tersebut dibuktikan dengan hasil uji $t$ dimana nilai $t_{\text {hitung }}$ sebesar $-1,994$ dan $t_{\text {tabel }}$ sebesar 2,056, sehingga $t_{\text {hitung }}(-1,994)<t_{\text {tabel }}(2,056)$ dan dengan nilai signifikan yang lebih besar dari 0,05 yaitu sebesar 0,057 $(0,057>0,05)$. Dengan demikian, dapat diketahui bahwa $\mathrm{H}_{0}$ diterima dan $\mathrm{H}_{1}$ ditolak, yang berarti tidak ada pengaruh yang signifikan antara debt to equity ratio terhadap harga saham. Temuan penelitian ini sejalan dengan hasil penelitian terdahulu yang membuktikan pengaruh negatif DER terhadap harga saham dan harga saham syari'ah (Kelana, Mardani dan Wahono 2017, Megawati 2018), tetapi tidak membuktikan signifikansi pengaruh DER terhadap harga saham (Manoppo, Tewal dan Hasan Jan 2017). Hal tersebut mengindikasikan bahwa para investor tidak mempertimbangkan sejauh mana penggunaan utang jika dibandingkan dengan ekuitas yang dimiliki perusahaan.

\subsubsection{Pengaruh Current Ratio (CR) Terhadap Harga Saham}

Berdasarkan hasil uji t pada tabel 10 diketahui bahwa current ratio tidak berpengaruh signifikan terhadap harga saham. Hal tersebut dibuktikan dengan hasil uji t dimana nilai $t_{\text {hitung }}$ sebesar $-1,043$ dan $t_{\text {tabel }}$ sebesar 2,056, sehingga $t_{\text {hitung }}(-1,043)<t_{\text {tabel }}(2,056)$ dan dengan nilai signifikan yang lebih besar dari 0,05 yaitu sebesar 0,307 $(0,307>0,05)$. Dengan demikian, dapat diketahui bahwa $\mathrm{H}_{0}$ diterima dan $\mathrm{H}_{1}$ ditolak, yang berarti tidak ada pengaruh yang signifikan antara current ratio terhadap hargasaham. Temuan penelitian ini sejalan dengan hasil penelitian terdahulu yang membuktikan pengaruh CR terhadap harga saham dan harga saham syari'ah (Idamanti 2016, Megawati 2018), tetapi tidak membuktikan signifikansi pengaruh CR terhadap 


\section{Buana Akuntansi}

Vol. 5 No. 2

ISSN 2528-1119

E-ISSN 2580-5452

harga saham (Kelana, Mardani dan Wahono 2017, Manoppo, Tewal dan Hasan Jan 2017). Hal tersebut mengindikasikan bahwa para investor tidak mempertimbangkan likuiditas perusahaan dalam mengambil keputusan berinvestasi.

\subsubsection{Pengaruh Net Profit Margin (NPM), Debt to Equity Ratio (DER), Current Ratio (CR), terhadap Harga Saham \\ Berdasarkan hasil uji-F pada tabel 11 diketahui bahwa perolehan F-hitung sebesar 2,395, untuk mengetahui nilai $\mathrm{F}_{-}$tabel maka dihitung nilai $\mathrm{df}_{1}=\mathrm{k}-1$ dan $\mathrm{df}_{2}=\mathrm{n}-\mathrm{k}$, dimana $\mathrm{k}$ adalah jumlah variabel dan $n$ adalah jumlah sampel. Nilai $\mathrm{df}_{1}=4-1=3$ dan nilai $\mathrm{df}_{2}=30-4=26$, sehingga $F_{\text {tabel }}$ yang diperoleh dengan signifikansi 0,05 adalah 2,980. Berdasarkan perhitungan tersebut, dapat diketahui bahwa nilai $\mathrm{F}_{\text {hitung }}<\mathrm{F}_{\text {tabel }}$ atau 2,395 $<2,980$ sehingga variabel independen tidak memiliki pengaruh signifikan secara simultan terhadap variabel dependen. hal ini dibuktikan dari hasil signifikan 0,091 > 0,05, sehingga keputusan yang diambil adalah $\mathrm{H}_{0}$ diterima dan $\mathrm{H}_{4}$ ditolak. Dengan demikian, dapat diketahui bahwa semua variabel independen yang terdiri dari net profit margin, debt to equity ratio, dan current ratio tidak berpengaruh secara simultan terhadap harga saham syariah dan hasilnya tidak sejalan dengan penelitian terdahulu.}

\section{Kesimpulan dan Saran}

Berdasarkan analisis data dan pembahasan hasil penelitian, kesimpulan penelitian ini yaitu:

1. Secara parsial variabel Net Profit Margin (NPM) tidak berpengaruh terhadap harga saham di Jakarta Islamic Index (JII) periode 2014-2018. Jadi hipotesis pertama yang menyatakan bahwa NPM berpengaruh terhadap harga saham ditolak.

2. Secara parsial variabel Debt to Equity Ratio (DER) tidak berpengaruh terhadap harga saham di Jakarta Islamic Index (JII) periode 2014-2018. Jadi hipotesis ke-dua yang menyatakan bahwa DER berpengaruh terhadap harga saham ditolak.

3. Secara parsial variabel Current Ratio (CR) tidak berpengaruh terhadap harga saham di Jakarta Islamic Index (JII) periode 2014-2018. Jadi hipotesis ke-tiga yang menyatakan bahwa CR berpengaruh terhadap harga saham ditolak.

4. Secara parsial variabel Net Profit Margin (NPM), Debt to Equity Ratio (DER), Current Ratio (CR) tidak berpengaruh terhadap harga saham di Jakarta Islamic Index (JII) periode 2014-2018. Jadi hipotesis ke-empat yang menyatakan bahwa NPM, DER, CR berpengaruh terhadap harga saham ditolak.

Saran penelitian ini yaitu:

1. Peneliti selanjutnya melakukan penelitian dengan periode pengamatan yang lebih lama, sehingga memberikan hasil yang lebih besar untuk memperoleh kondisi yang sebenarnya dan memberikan hasil yang lebih akurat lagi.

2. Peneliti selanjutnya diharapkan menambahkan variabel lain untuk mengetahui faktor apa saja yang dapat mempengaruhi harga saham.

3. Peneliti selanjutnya diharapkan dapat menambah jumlah sampel penelitian sehingga akan memberikan hasil yang lebih akurat. 


\section{Daftar Pustaka}

Bapepam. "Peraturan Nomor IX.A.13 : Penerbitan Efek Syariah KEP-130/BL/2006, 23 Nopember 2006." Peraturan, Jakarta, 2006.

Dewan Syari'ah Nasional. 020 - Fatwa Dewan Syari'ah Nasional No: 20/DSN-MUI/IV/2001 | Pedoman Pelaksanaan Investasi untuk Reksa Dana Syariah. Fatwa, Jakarta: Majelis Ulama Indonesia (MUI), 2001.

EIMI. Kinerja Konstituen Jakarta Islamic Index (JII) Tahun 2016: Bagian Pertama. April 27, 2017. https://www.syariahsaham.com/2017/04/kinerja-konstituen-jakarta-islamic.html (accessed Juni 13, 2020).

Fahmi, Irham. Analisis Laporan Keuangan. Bandung: Alfabeta, 2017.

Husain, T., dan A. Syniuta. "Audit Fee and "The Big-Four": A Comparative Study at Initial Public Offerings (IPO) Companies in Indonesia Stock Exchange (IDX)." Multidisciplinary European Academic Journal (A.O. Syniuta Publisher) 2, no. 4 (2020): 1-7.

Husain, T, Sarwani, Nardi Sunardi, and Lisdawati. "Firm's Value Prediction Based on Profitability Ratios and Dividend Policy." Finance \& Economics Review (Research \& Innovation Initiative) 2, no. 2 (2020): 13-26.

Idamanti, Nunuk. "Pengaruh Likuiditas, Profitabilitas dan Penjualan terhadap Harga Saham Perusahaan Makanan dan Minuman yang Tercatat di BEI Tahun 2010-2014." Jurnal Manajemen Bisnis 6, no. 2 (2016): 118-127.

Kartika, Andi. "Faktor-Faktor Yang Mempengaruhi Kelengkapan Pengungkapan Laporan Keuangan pada Perusahaan Manufaktur yang Terdaftar di Bursa Efek Indonesia." Kajian Akuntansi 1, no. 1 (Pebruari 2009): 29-47.

Kasmir, Dr. Analisis Laporan Keuangan. Jakarta: PT. Rajagrafindo Persada, 2016.

Kelana, Dian Ramadhan, Ronny Malavia Mardani, and Budi Wahono. "Pengaruh Return on Asset (ROA), Current Ratio (CR), Earning Per Share (EPS), dan Debt to Equity Ratio (DER) Terhadap Harga Saha Pada Perusahaan Manufaktur di Bursa Efek Indonesia (BEI) Tahun 2015-2017." e-Jurnal Riset Manajemen (Prodi Manajemen Fakultas Ekonomi Unisma) 08, no. 04 (Agustus 2017): 93-106.

Manoppo, Vera Ch. O., Bernhard Tewal, and Arrazi Bin Hasan Jan. "Pengaruh Current Ratio, DER, ROA dan NPM Terhadap Harga Saham Pada Perusahaan Food and Beverages yang Terdaftar di BEI (Periode 2013-2015)." Jurnal EMBA 5, no. 2 (Juni 2017): 1813-1822.

Megawati. Pengaruh Beta Saham dan Faktor Fundamental Keuangan Terhadap Harga Saham Syariah. Skripsi, Makassar: FEB Islam, Universitas Islam Negeri Alauddin, 2018.

Nurfadillah, Mursidah, Dewi Kamaratih, and Hamka. "Analisis Pengaruh Current Ratio, Return on Assets, Debt Equity Ratio dan Tingkat Pertumbuhan terhadap Kebijakan Dividen." Jurnal Ekonomi dan Manajemen 13, no. 1 (2019).

Oktaviani, Yeni. Pengaruh Current Ratio (CR), Debt to Total Assets Ratio (DAR), Debt to Equity Ratio (DER), dan Net Profit Margin (NPM) Terhadap Harga Saham Pada Perusahaan Food and Beverages yang Terdaftar Di Bursa Efek Indonesia Periode 2013-2016. Article, Tanjung Pinang, Riau: Universitas Maritim Raja Ali Haji, 2018. 


\section{Buana Akuntansi}

Purba, Imelda R. "Pengaruh Rasio Likuiditas dan Rasio Solvabilitas terhadap Earning per Share pada Perusahaan Sektor Industri Dasar dan Kimia yang Terdaftar di Bursa Efek Indonesia." JRAK 1, no. 1 (Maret 2015): 34-57.

Sapariyah, Rina Ani, Achmad Choerudin, Yanti Setyorini, and Yenni Khristiana. "Financial Performance of Conventional and Syariah Banks: An Empirical Studies in Indonesia." Islamic Banking and Finance 5, no. 2 (December 2017): 9-14.

Undang-Undang RI. "UU Nomor19 Tahun 2008 tentang Surat Berharga Syariah Negara (SBSN)." Jakarta, 2008.

Yanti, Puji Isyanto, and Mohd Haizam Mohd Saudi. "Analysis of Financial Performance with Using Economic Value Added." International Journal of Psychosocial Rehabilitation, no. 7 (2020): 3362-3370. 